\title{
Crystal Forms of Chromium Orthophosphate
}

\author{
Barbara M. Sullivan and Howard F. McMurdie
}

\begin{abstract}
There is no evidence for the existence of any crystalline hydrate of chromium orthophosphate other than the hexahydrate. This breaks down near $130^{\circ} \mathrm{C}$ to an amorphous material. If the unstrained and coarse hexahydrate is heated, it recrystallizes at $1,014^{\circ} \mathrm{C}$ to an unstable, fine-grained compound $\left(\beta \mathrm{CrPO}^{4}\right)$. If the original hydrate is ground and thus strained, it will form a stable compound $\left(\alpha \mathrm{CrPO}^{4}\right)$ at $972^{\circ} \mathrm{C}$. X-ray diffraction powder patterns are given for the three crystalline forms, and the general relation of chromium orthophosphate hexahydrate to other hydrates is discussed.
\end{abstract}

\section{Introduction}

A study of the forms of chromium orthophosphate was suggested by the National Institutes of Health. They needed a radioactive material that was insoluble and nontoxic. Chromium orthophosphate with radioactive phosphorus had been used in similar work [1]. ${ }^{1} \quad$ They found, however, that it was difficult to prepare a uniform anhydrous compound by heating the hexahydrate, inasmuch as the temperature of dehydration was very critical.

There are only a few previous studies of the compound reported in the literature. Joseph and Rae [2] in 1917 reported a violet hexahydrate, as well as a crystalline tetra- and dihydrate. In 1948 Clark and Tai [3] made X-ray powder patterns of the hexa- and tetrahydrates and found them identical, whereas pat-terns of the dihydrate and anhydrous forms indicated amorphous material.

\section{Materials and Equipment}

The samples studied here were given to the Bureau by the National Institutes of Health. They were prepared as hexahydrate $\left(\mathrm{CrPO}_{4} \cdot 6 \mathrm{H}_{2} \mathrm{O}\right)$, using a modification of the method of Joseph and Rae [2] described in detail by Ness, Smith, and Evans [4]. Differential thermal-analysis studies were made by standard methods [5], using a program controller, a direct-current amplifier, and automatic recording. X-ray patterns were made on a North American Philips High-Angle Geiger Counter Spectrometer, using the techniques described by Swanson and Tatge [6] to obtain accurate spacings and intensities. In some cases patterns were made with the sample at high temperatures in the furnace described by Van Valkenburg and McMurdie [7]. $\mathrm{CuK} \alpha$ radiation was used in all cases $(\lambda=1.5405)$.

\section{Chromium Orthophosphate Hexahydrate}

The hexahydrate, as shown in figure 1 , is violet in color, prismatic and twinned in habit, biaxial negative with $\alpha=1.568, \beta=1.591, \gamma=1.599,2 V=13^{\circ}$. The $d$ spacings and relative intensities of the powder pattern are shown in table 1 .

${ }_{1}^{1}$ Figures in braekets indicate the literature references at the end of this paper.

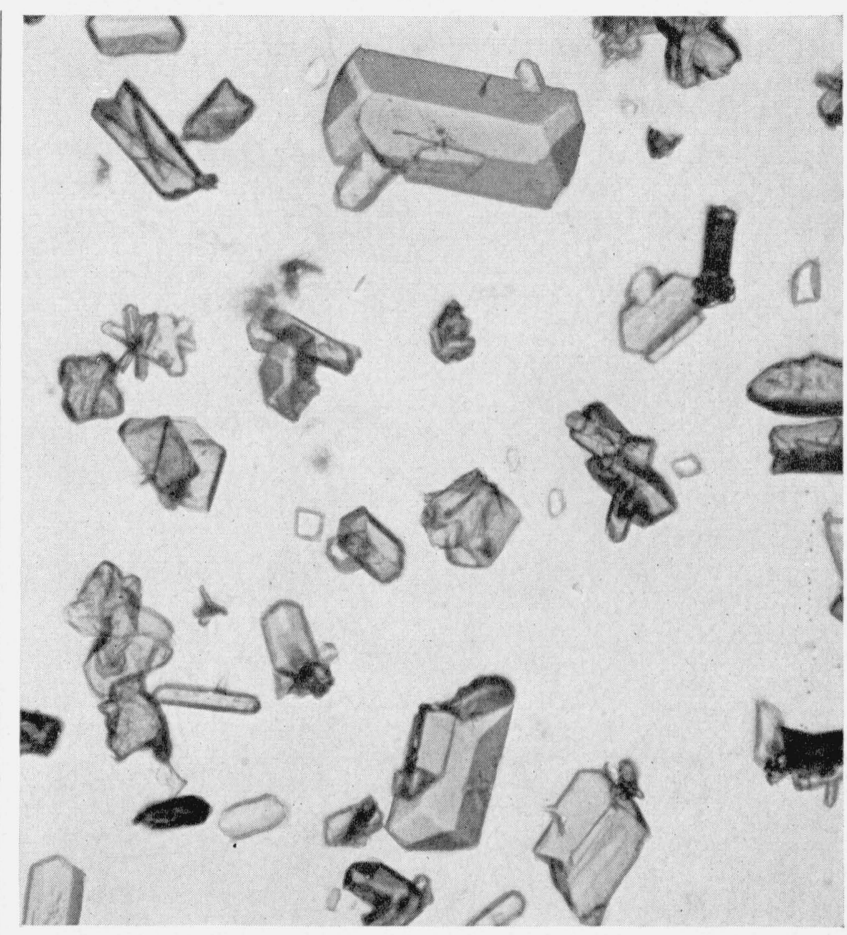

Figure 1. Chromium orthophosphate hexahydrate; $\times 150$.

TABLE 1. d-Spacings and relative intensities of chromium orthophosphate hexahydrate

\begin{tabular}{|c|c|c|c|c|c|c|c|}
\hline$d$ & $I$ & $d$ & $I$ & $d$ & $I$ & $d$ & $I$ \\
\hline $\begin{array}{l}5.76 \\
5.63 \\
5.35 \\
5.27 \\
4.87\end{array}$ & $\begin{array}{r}6 \\
28 \\
11 \\
24 \\
40\end{array}$ & $\begin{array}{l}3.46 \\
3.33 \\
3.29 \\
\text { 3. } 05 \\
2.95\end{array}$ & $\begin{array}{r}30 \\
7 \\
6 \\
8 \\
9\end{array}$ & $\begin{array}{l}2.57 \\
2.48 \\
2.47 \\
2.43 \\
2.38\end{array}$ & $\begin{array}{r}12 \\
9 \\
8 \\
4 \\
4\end{array}$ & $\begin{array}{l}1.924 \\
1.903 \\
1.874 \\
1.808 \\
1.701\end{array}$ & $\begin{array}{r}12 \\
4 \\
6 \\
8 \\
10\end{array}$ \\
\hline $\begin{array}{l}4.78 \\
\text { 4. } 23 \\
\text { 4. } 07 \\
\text { 3. } 85 \\
\text { 3. } 75\end{array}$ & $\begin{array}{r}22 \\
100 \\
26 \\
42 \\
8\end{array}$ & $\begin{array}{l}2.87 \\
2.82 \\
2.80 \\
2.79 \\
2.69\end{array}$ & $\begin{array}{r}8 \\
24 \\
22 \\
21 \\
10\end{array}$ & $\begin{array}{l}\text { 2. } 24 \\
\text { 2. } 22 \\
\text { 2. } 18 \\
\text { 2. } 12 \\
\text { 2. } 04\end{array}$ & $\begin{array}{r}10 \\
7 \\
7 \\
4 \\
3\end{array}$ & $\begin{array}{l}\text { 1. } 677 \\
\text { 1. } 527 \\
\text { 1. } 488 \\
\text { 1. } 450\end{array}$ & $\begin{array}{l}4 \\
2 \\
3 \\
3\end{array}$ \\
\hline
\end{tabular}

The chromium orthophosphate hexahydrate, when heated, begins to lose water at about $100^{\circ} \mathrm{C}$ and loses approximately 95 percent of the total between $100^{\circ}$ and $400^{\circ} \mathrm{C}$. It is not completely dehydrated until about $800^{\circ} \mathrm{C}$. The details of the losses have been discussed by Ness, Smith, and Evans [4]. 
They showed that while most of the loss is near $130^{\circ}$ $\mathrm{C}$, the vapor-pressure curve indicates no sharp breaks, and there is considerable loss, even up to $800^{\circ} \mathrm{C}$. With the initial loss of water, the material changes first to a bright-green color and then becomes dark brown. The X-ray powder pattern of material

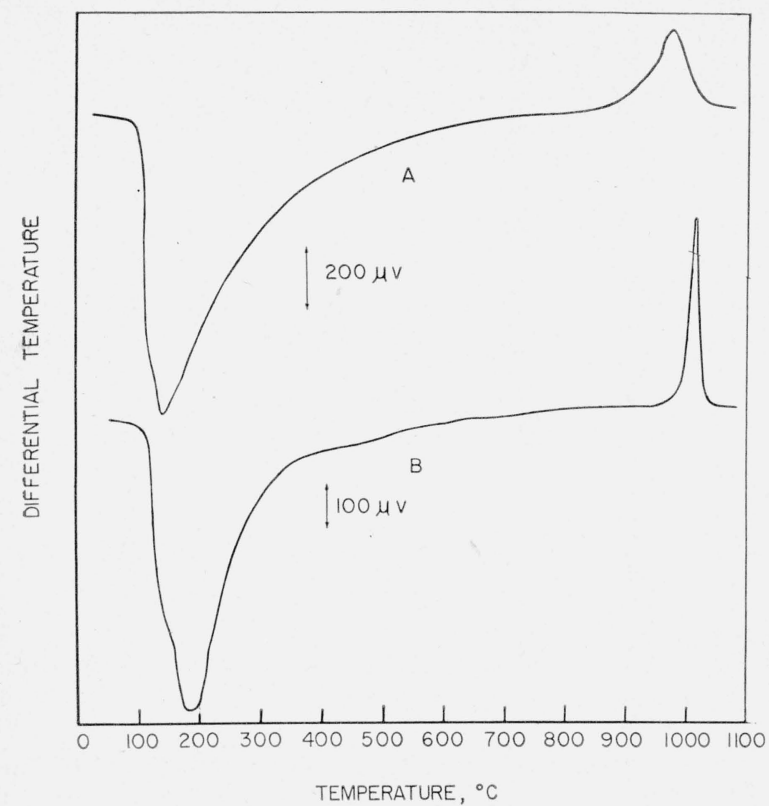

Figure 2. Differential thermal analysis curves of $\mathrm{CrPO}_{4} \cdot 6 \mathrm{H}_{2} \mathrm{O}$ heated at $121 / 2^{\circ} /$ minute.

A, Sample heated after grinding. $\alpha \mathrm{CrPO}_{4}$ forms at $972^{\circ} \mathrm{C} . \quad \mathrm{B}$, Sample heated unground. $\beta \mathrm{CrPO}_{4}$ forms at $1,014^{\circ} \mathrm{C}$.

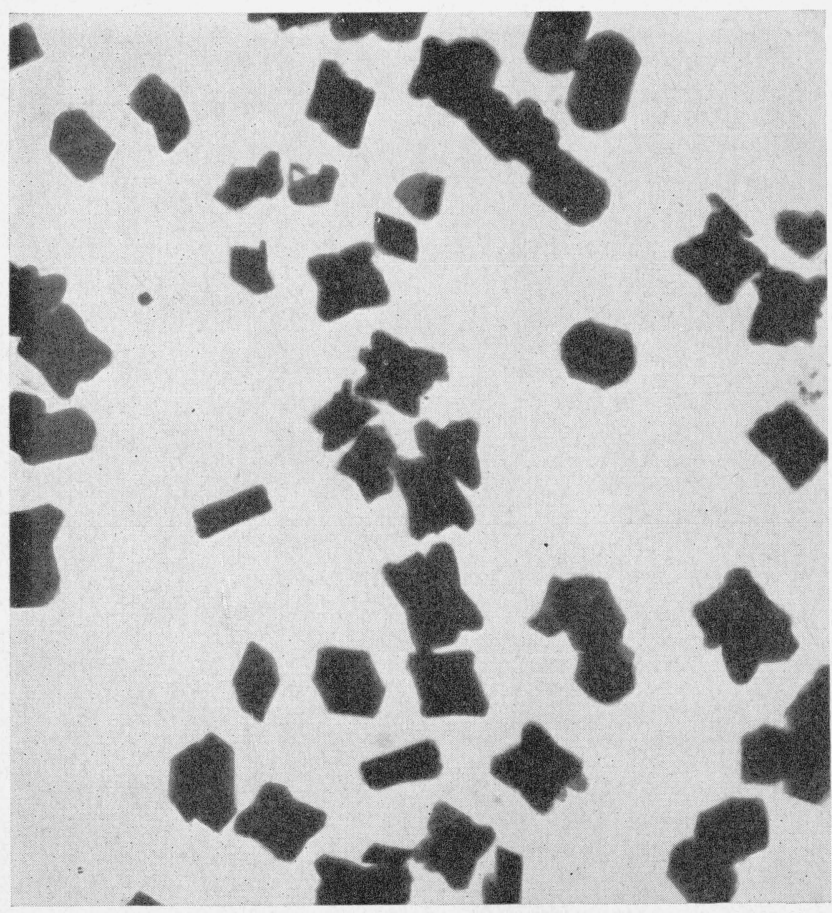

Figure 3. Amorphous material obtained by heating chromium orthophosphate hexahydrate at $600^{\circ} \mathrm{C}$ for $66^{1 / 2}$ hours; $\times 150$. heated up to $130^{\circ} \mathrm{C}$ becomes gradually weaker but is otherwise unchanged. Above $130^{\circ} \mathrm{C}$ the pattern indicates amorphous material. No evidence was found here for the existence of the crystalline tetrahydrate reported by others [2,3]. It was reported as being produced by boiling the hexhydrate in $\mathrm{H}_{2} \mathrm{O}$ for half an hour. Material treated in this manner was bright green and showed a weak X-ray pattern of the hexahydrate. Under the microscope it appeared as a mixture of the crystalline hexahydrate and amorphous material. Weight-loss determinations of the boiled material indicated the loss of approximately 1 molecule of water.

The differential thermal analysis patterns of chromium orthophosphate hexahydrate, both ground and unground, heated at $12 \frac{1}{2} \mathrm{deg} / \mathrm{min}$, are given in figure 2. The large endothermic break near $130^{\circ} \mathrm{C}$ is caused by the loss of water and the breakdown of the crystal structure. Above that temperature the material appears dark brown and almost opaque in the microscope, and the X-ray diffraction pattern indicates that it is amorphous. Figure 3 shows a sample that has been held at $600^{\circ} \mathrm{C}$ for $66 \frac{1}{2}$ hours. It may be noted that the external shape of the original hexahydrate is retained. This is typical of material heated in this temperature range.

\section{Anhydrous Chromium Orthophosphate}

The exothermic breaks on the differential thermalanalysis curves (fig. 2) near $1,000^{\circ} \mathrm{C}$ indicate the crystallization of anhydrous chromium orthophosphate. Two different crystal forms exist, one of which is stable. The stable high-temperature form is designated $\alpha$, and the lower, unstable form, $\beta$. The $\beta$ form is produced when unground material is heated and its formation produces the sharp break at $1,014^{\circ} \mathrm{C}$. At higher temperatures this form gradually changes to $\alpha$ chromium orthophosphate. Although the X-ray pattern does not show the $\alpha$ form until it has been heated to $1,400^{\circ} \mathrm{C}$, microscopic examination indicates its formation in small amounts as low as $1,200^{\circ} \mathrm{C}$. Fairly pure $\beta$ chromium orthophosphate can be formed when the unground hexahydrate is heated a short time between $1,000^{\circ}$ and $1,100^{\circ} \mathrm{C}$, but prolonged heating near $1,100^{\circ} \mathrm{C}$ results in the formation of a noticeable amount of the $\alpha$ form. When the hexahydrate is ground before heating, the $\alpha$ form crystallizes with no intermediate step. At a heating rate of $12 \frac{1}{2} \mathrm{deg} / \mathrm{min}$ this takes place with an exothermic break at $972^{\circ} \mathrm{C}$. In the high-temperature X-ray furnace [7] only the $\alpha$ form was found, as it was necessary to grind the sample to hold it in position.

Tables 2 and 3 list the $d$ spacings and relative intensities of the two anhydrous forms. A typical example of the $\beta$ form is shown in figure 4 . The very fine highly birefringent particles show no extinction positions and have an average index of 1.908 . The $\alpha$ form (fig. 5) is strongly pleochroic, changing from bright green to deep blue. It is biaxial positive with a very large $2 \mathrm{~V}$, and with $\alpha=1.761$ (blue), and $\gamma=1.844$ (green). The presence of small amounts 


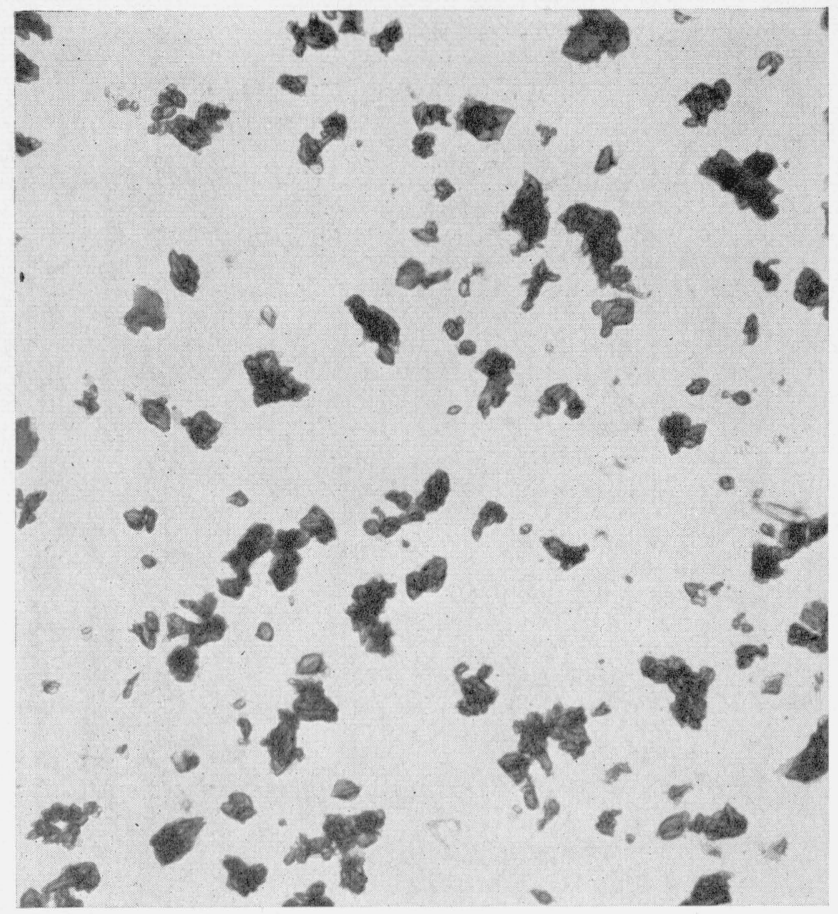

Figure 4. Anhydrous chromium orthophosphate ( $\beta$ form) obtained by heating the unground hexahydrate, to $1,100^{\circ} \mathrm{C}$ in the differential thermal-analysis furnace; $\times 150$.

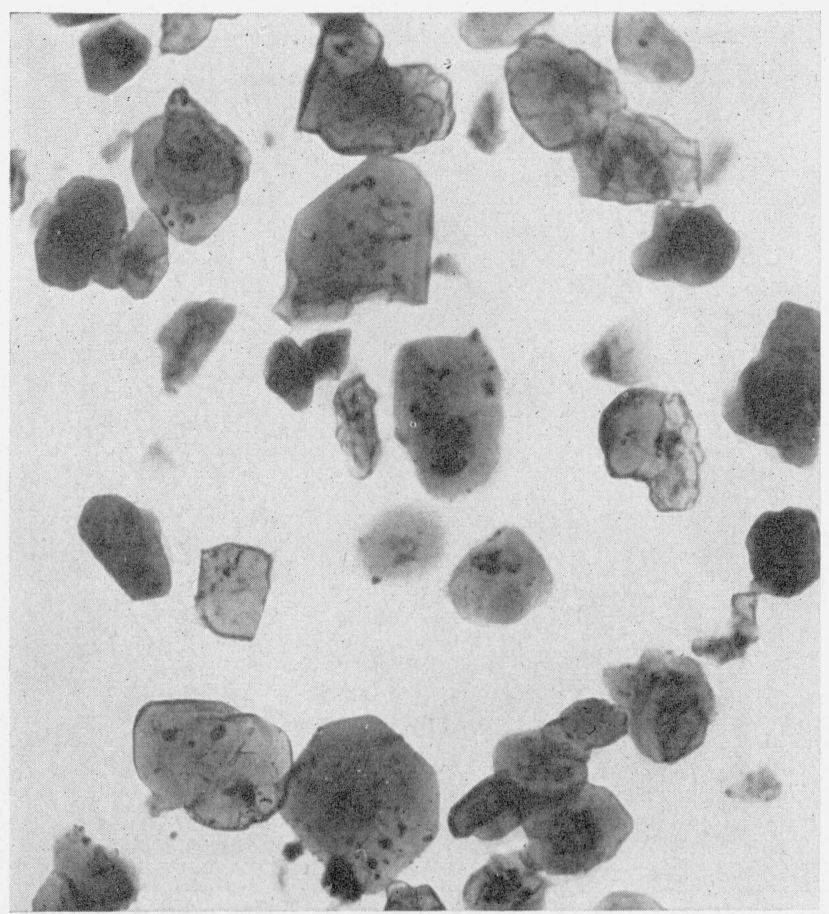

Figure 5. Anhydrous chromium orthophosphate ( $\alpha$ form) obtained by heating the hexahydrate at $1,500^{\circ} \mathrm{C}$ for 2 hours; $\times 140$.

of the $\alpha$ form is readily detected by the microscope because of its unusual pleochroism.

The $\alpha$ form was stable and unmelted up to $1,800^{\circ} \mathrm{C}$, the limit of available furnaces.
TABLE 2. d-Spacings and relative intensities of anhydrous chromium orthophosphate $-\beta$ form

\begin{tabular}{|c|c|c|c|c|c|c|c|}
\hline$d$ & $I$ & $d$ & $I$ & $d$ & $I$ & $d$ & $I$ \\
\hline 4. 30 & 74 & 2. 03 & 5 & 1. 621 & 5 & 1. 337 & \\
\hline 3.88 & 41 & 1. 975 & 37 & 1. 531 & 12 & 1.319 & 6 \\
\hline 3.51 & 95 & 1. 938 & 20 & 1. 502 & 5 & 1. 290 & 10 \\
\hline 3.27 & 51 & 1.845 & 4 & 1.484 & 4 & 1. 268 & 14 \\
\hline 2. 58 & 50 & 1. 808 & 6 & 1. 473 & 16 & 1. 202 & 12 \\
\hline 2. 48 & 100 & 1. 760 & 28 & 1. 443 & 7 & & \\
\hline 2. 31 & 54 & 1. 681 & 2 & 1.433 & 10 & & \\
\hline 2. 15 & 5 & 1. 637 & 20 & 1.383 & 37 & & \\
\hline
\end{tabular}

TABLE 3. d-Spacings and relative intensities of anhydrous chromium orthophosphate- $\alpha$ form

\begin{tabular}{|c|c|c|c|c|c|c|c|}
\hline$d$ & $I$ & $d$ & $I$ & $d$ & $I$ & $d$ & $I$ \\
\hline $\begin{array}{l}\text { 6. } 45 \\
\text { 5. } 67 \\
\text { 5. } 40 \\
5.20\end{array}$ & $\begin{array}{r}17 \\
45 \\
100 \\
48\end{array}$ & $\begin{array}{l}\text { 3. } 04 \\
\text { 2. } 77 \\
\text { 2. } 74 \\
\text { 2. } 69\end{array}$ & $\begin{array}{l}22 \\
13 \\
51 \\
40\end{array}$ & $\begin{array}{l}\text { 2. } 03 \\
\text { 1. } 925 \\
1.796 \\
1.760\end{array}$ & $\begin{array}{r}13 \\
5 \\
3 \\
8\end{array}$ & $\begin{array}{l}1.575 \\
1.553 \\
1.528 \\
1.519\end{array}$ & $\begin{array}{l}6 \\
3 \\
8 \\
6\end{array}$ \\
\hline $\begin{array}{l}4.14 \\
3.83 \\
3.55 \\
3.15\end{array}$ & $\begin{array}{l}4 \\
3 \\
7 \\
9\end{array}$ & $\begin{array}{l}2.60 \\
2.49 \\
2.17 \\
2.07\end{array}$ & $\begin{array}{r}26 \\
7 \\
18 \\
5\end{array}$ & $\begin{array}{l}1.703 \\
\text { 1. } 686 \\
\text { 1. } 629 \\
1.612\end{array}$ & $\begin{array}{r}13 \\
3 \\
-\quad 4 \\
5\end{array}$ & $\begin{array}{l}\text { 1. } 507 \\
\text { 1. } 447 \\
1.443\end{array}$ & $\begin{array}{l}3 \\
3 \\
2\end{array}$ \\
\hline
\end{tabular}

\section{Discussion}

No evidence was found in this investigation for the existence of any crystalline hydrate of chromium orthophosphate other than the hexahydrate. The dehydration is not completed below $800^{\circ} \mathrm{C}$ because of the formation of an amorphous material that has an extremely large absorbing surface. The dehydration curves of Ness, Smith, and Evans [4] do not show sharp breaks as do compounds that form new crystal phases immediately following dehydration, but are much more gradual, which, it is believed, is typical of conditions when amorphous phases exist for scme time before recrystallization.

The formation of an amorphous phase that exists over a wide temperature range is of special interest here. It is known that kaolinite forms such a phase between its decomposition at about $550^{\circ} \mathrm{C}$ and the

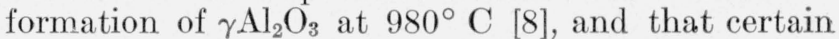
other silicates, such as pyrophyllite [9], pass through an amorphous state. These compounds differ in two distinct ways from chromium orthophosphate hexahydrate. In these silicates the "water" is in the form of $\mathrm{OH}$ groups and is lost above $500^{\circ} \mathrm{C}$, and the silicate groups are linked together with shared $\mathrm{O}$ atoms. In the case of $\mathrm{CrPO}_{4} \cdot 6 \mathrm{H}_{2} \mathrm{O}$, however, it is reasonable to expect that the water is present as molecular water surrounding the $\mathrm{Cr}$ atoms, and the $\mathrm{PO}_{4}$ groups are discrete unlinked groups.

Aluminum and iron orthophosphates have inversions and structures similar to those of silica [10]. It was at first thought that chromium orthophosphate was related to silica in an analogous manner, but no evidence was found to support this.

The formation of an unstable form of the anhydrous compound, when unground material is used, is evidence that the $\beta$ form is more closely allied to the original structure than is the $\alpha$ form. When 
the starting material is ground with an attendant increase in surface, it approaches equilibrium more rapidly and the $\beta$ form is not obtained. It is apparent that the $\beta$ form is not stable above $973^{\circ} \mathrm{C}$.

The formation of a preliminary unstable phase is not an unusual occurrence; the formation of $\gamma \mathrm{Al}_{2} \mathrm{O}_{3}$ in kaolinite is such a case [8]. When $3 \mathrm{CaO} \cdot \mathrm{Al}_{2} \mathrm{O}_{3} \cdot 6 \mathrm{H}_{2} \mathrm{O}$ is dehydrated, the first crystal phases formed are $12 \mathrm{CaO} .7 \mathrm{Al}_{2} \mathrm{O}_{3}$ and $\mathrm{CaO}$, whereas the final equilibrium compound is the single phase $3 \mathrm{CaO} \cdot \mathrm{Al}_{2} \mathrm{O}_{3}$ [11]. Grim and Bradley [9] have noted the occurrence of various unstable phases in dehydration of clays and other silicates.

\section{Summary}

There is a single crystalline hydrate of chromium orthophosphate $\left(\mathrm{CrPO}_{4} .6 \mathrm{H}_{2} \mathrm{O}\right)$ that is violet, platy, biaxial negative with $\alpha=1.568, \beta=1.591, \gamma=1.599$, and $2 V=13^{\circ}$.

This hydrate breaks down near $130^{\circ} \mathrm{C}$ to an amorphous material that retains some water up to $800^{\circ} \mathrm{C}$.

If the original material is unstrained and coarse, it will recrystallize on heating at about $1,020^{\circ} \mathrm{C}$ to an unstable fine-grained $\beta \mathrm{CrPO}_{4}$ with an average index of refraction of 1.908 .

If the original hydrate is ground and thus strained, the material will form a stable compound $\left(\alpha \mathrm{CrPO}_{4}\right)$ that is highly pleochroic, biaxial negative with $\alpha=1.761, \gamma=1.844$, and $2 V$ large.

\section{References}

[1] H. Allen, L. H. Hempelmann, Jr., and N. A. Womack, The effect of insoluble radiophosphorus (chromium phosphate) when applied interstitially in the treatment of adenocarcinoma of the mamma in mice, Cancer Research 5, 239 (1945).

[2] A. F. Joseph and W. N. Rae, Chromium phosphate, J. Chem. Soc. III, 196 (1917).

[3] G. L. Clark and A. P. Tai, Phosphate coating of aluminum and polymorphism of chromium phosphate, Science 107, 505 (1948).

[4] A. T. Ness, R. E. Smith, and R. L. Evans, The preparation and some properties of normal and radioactive chromic phosphate, J. Am. Chem. Soc. (publication pending).

[5] S. Speil, L. H. Berkelhamer, J. Pask, and B. Davies, Differential thermal analysis, U. S. Bureau of Mines Tech. Pap. 664 (1945).

[6] H. E. Swanson and E. Tatge, Standard X-ray diffraction patterns, J. Research NBS 46, 318 (1951) RP2202.

[7] A. Van Valkenburg, Jr., and H. F. McMurdie, Hightemperature X-ray diffraction apparatus, J. Research NBS 38, 415 (1947) RP1782.

[8] H. Insley and R. H. Ewell, Thermal behavior of kaolin minerals, J. Research NBS 14, 615 (1935) RP792.

[9] W. F. Bradley and R. E. Grim, High-temperature thermal effects of clay and related materials, Am. Mineral. 36, 182 (1951).

[10] M. J. Buerger, Crystals based on the silica structure, Am. Mineral. 33, 751 (1948).

[11] W. G. Schneider and T. Thorvaldson, The dehydration of tricalcium aluminate hexahydrate, Can. J. Research 19 [B], 123 (1941).

Washington, October 10, 1951. 